\title{
Charakterystyka statutu Uniwersytetu Papieskiego Jana Pawła II w Krakowie
}

Kodeks prawa kanonicznego postanawia: „Każdy uniwersytet i wydział kościelny musi posiadać własne statuty i program studiów, zatwierdzone przez Stolicę Apostolską" (kan. 816, § 2). Uniwersytet Papieski Jana Pawła II (dalej: UPJPII) należy do kategorii uniwersytetów kościelnych i winien posiadać własny statut uchwalony przez senat Uniwersytetu i zatwierdzony przez Stolicę Apostolską. Tymi sprawami w Stolicy Apostolskiej zajmuje się Kongregacja Edukacji Katolickiej. Ojciec Święty Benedykt XVI w dniu 19 czerwca 2009 roku podniósł Papieską Akademię Teologiczną w Krakowie (dalej: PAT) do godności Uniwersytetu. W związku z tym zaistniała potrzeba przygotowania, uchwalenia i zatwierdzenia nowego statutu uczelni. Statut PAT został zatwierdzony przez Kongregację Edukacji Katolickiej 16 października 1991 roku w formie Donec aliter provideatur ${ }^{1}$. Przy tworzeniu Uniwersytetu Papieskiego Kongregacja zażądała nowego statutu, który został zatwierdzony 5 lutego 2010 roku $^{2}$.

\section{Geneza}

Długie i interesujące są dzieje troski Kościoła katolickiego o naukę i oświatę. Sięgają one pierwszych wieków jego historii. Ważnym etapem tego wielowiekowego procesu było powołanie do życia uniwersytetów „przybytków nauki”, które powstały w łonie Kościoła w okresie Średniowiecza ${ }^{3}$. W ten nurt rozwoju uniwersytetów w dalszych wiekach włączyły się społeczności świeckie, próbując czasem eliminować element kościelny, a nawet wprowadzić na niektórych uniwersytetach klimat wrogi Kościołowi. Wszystko to nie przeszkodziło w dalszym rozwoju uniwersytetów

${ }^{1}$ Dekret Kongregacji Edukacji Katolickiej, 16 X 1991, został opublikowany w: Statut Papieskiej Akademii Teologicznej w Krakowie (dalej: Statut PAT), oprac. J. Dyduch, Kraków 1992, s. 119.

${ }^{2}$ Dekret Kongregacji Edukacji Katolickiej, 5 II 2010, Archiwum UPJPII.

${ }^{3}$ Por. J. Umiński, Historia Kościoła, t. 1, wyd. 4, Opole 1959, s. 507. 
prowadzonych przez instytucje Kościoła katolickiego. W tym procesie ukształtowały się dwie formy uczelni: uniwersytety katolickie i uniwersytety kościelne ${ }^{4}$.

To rozróżnienie było owocem kulturotwórczej i ewangelizacyjnej działalności Kościoła. Dzięki niej wyrosła potrzeba ustanowienia odrębnych zasad postępowania dla uniwersytetów katolickich, inspirowanych publiczną i powszechną obecnością idei chrześcijańskich i dla uniwersytetów kościelnych inspirujących swe badania Objawieniem Bożym 5 . To rozróżnienie nie występuje w Kodeksie prawa kanonicznego z 1917 roku, który podaje normy odnoszące się do uniwersytetów katolickich, niezależnie od tego, jakimi dziedzinami wiedzy się zajmują. Odrębne normy dotyczące nauk kościelnych wykładanych na uniwersytetach i fakultetach katolickich zawiera konstytucja apostolska papieża Piusa XI Deus scientiarum Dominus ${ }^{6}$. Dokonała ona odnowy wyższych studiów w zakresie nauk kościelnych ${ }^{7}$.

Dalszym etapem rozwoju organizacji nauk kościelnych była konstytucja apostolska papieża Jana Pawła II Sapientia Christiana ${ }^{8}$. Poświęcona jest ona uniwersytetom i fakultetom kościelnym. Uniwersytety kościelne zajmują się przede wszystkim naukami teologicznymi i tymi gałęziami wiedzy, które są z nimi powiązane. Jednak konstytucja Sapientia Christiana, biorąc pod uwagę ewangelizacyjne zadania Kościoła, poszerza optykę dyscyplin naukowych, mających być przedmiotem zainteresowania uniwersytetów kościelnych:

Powiązanie z posługą ewangelizacyjną powinno mieć miejsce również na wydziałach tych nauk, które wprawdzie nie posiadają szczególnego związku z chrześcijańskim objawieniem, ale mogą w dużej mierze pomóc w podejmowaniu dzieła ewangelizacji; z tej właśnie racji Kościół docenia je, eryguje jako wydziały kościelne i dlatego też zachowują one szczególny związek z kościelną hierarchią 9

Przywołana konstytucja Sapientia Christiana jest podstawowym dokumentem, który winien być uwzględniony w statutach poszczególnych uniwersytetów kościelnych: „Statuty każdego uniwersytetu lub wydziału, sporządzone zgodnie z przepisami obecnej konstytucji wymagają zatwierdzenia Kongregacji Edukacji Katolickiej”'10.

Uniwersytet Papieski Jana Pawła II w Krakowie jest typowym uniwersytetem kościelnym. Dlatego jego statuty są sformułowane w oparciu o zasady konstytucji Sapientia Christiana. Trzeba jednak dodać, że posiada ona w wielu przypadkach przepisy bardzo ogólne, jest bowiem przeznaczona dla całego Kościoła. Dlatego zezwala na wprowadzenie różnych norm i postanowień właściwych dla różnych

\footnotetext{
${ }^{4}$ Szerzej na ten temat, por. J. Dyduch, Rola uczelni kościelnych i katolickich w świetle prawodawstwa powszechnego, „Analecta Cracoviensia” 24 : 1992, s. 135-151.

${ }^{5}$ Por. S. Pasternak, Reorganizacja studiów kościelnych, szczególnie wykładów prawa kanonicznego w świetle „Sapientia Christiana”, „Prawo Kanoniczne” 23 : 1980, nr 3-4, s. 218.

${ }^{6} 24$ V 1931, „Acta Apostolicae Sedis” (dalej: AAS) 23 : 1931, s. 241.

${ }^{7}$ Por. P. Bączkowicz, Prawo kanoniczne, t. 2, Opole 1958, s. 504-505.

${ }^{8} 15$ IV 1979, AAS $71: 1979$, s. 469-499.

${ }^{9}$ Tamże, Wstęp, III.

${ }^{10}$ Tamże, art. 7.
} 
krajów, różnych tradycji i warunków kulturowych. Uniwersytet Papieski w Krakowie jest uczelnią młodą, bo utworzoną 19 czerwca 2009 roku, ale swoimi korzeniami, tradycjami i historią sięga XIV wieku. Ta wielowiekowa rzeczywistość musiała zostać uwzględniona w statucie Uniwersytetu.

Tę ścisłą więź UPJPII z historią i tradycjami teologicznej uczelni Krakowa wyraża statut w pierwszej, o znaczeniu podstawowym, normie:

Uniwersytet Papieski Jana Pawła II w Krakowie jest Uniwersytetem kościelnym kanonicznie erygowanym przez Stolicę Apostolską. Kontynuuje on, zgodnie ze współczesnymi potrzebami Kościoła w Polsce, historyczną misję Wydziału Teologicznego Uniwersytetu Jagiellońskiego i Papieskiej Akademii Teologicznej w Krakowie ${ }^{11}$.

Tak więc Uniwersytet Papieski jest najpierw kontynuacją Wydziału Teologicznego UJ. Obecność Wydziału Teologicznego w Uniwersytecie Krakowskim datuje się od 11 stycznia 1397 roku, który od tego czasu stał się uniwersytetem, gdyż poprzednio uczelnia krakowska stanowiła Studium generale. Według ówczesnych standardów uczelnia mogła stać się pełnoprawnym uniwersytetem dopiero wówczas, gdy posiadała Wydział Teologiczny erygowany przez papieża. Tak się stało w Krakowie w roku 1397, dzięki staraniom św. Jadwigi Królowej i jej męża Władysława Jagiełły. Podjęli oni starania u papieża Bonifacego IX, który bullą Eximiae devotionis affectus erygował Wydział Teologiczny w Studium generale dnia 11 stycznia 1397 roku. Papież postanowił: ,powagą apostolską niniejszym pismem postanawiamy i zarządzamy, ażeby w tym mieście odtąd w przyszłości po wieczne czasy był i mógł być Wydział Teologiczny"'12.

Tak więc z woli papieża Bonifacego IX i z woli królów Polski, Jadwigi i Władysława, Wydział Teologiczny jako istotny element wszedł w dzieje Uniwersytetu Krakowskiego, zwanego później Jagiellońskim. Wraz z całym Uniwersytetem służył Kościołowi i Ojczyźnie, dzielił jego losy, jego osiągnięcia i porażki. Ta więź Wydziału Teologicznego z Uniwersytetem Jagiellońskim zaznaczyła się szczególnie w pierwszych dziesiątkach XX wieku. Najpierw, po odzyskaniu niepodległości w 1918 roku, kiedy wspólnie budowano naukę i kulturę polską, a potem podczas okupacji. Trudno nie wspomnieć tragicznych wydarzeń, jakimi były najazd hitlerowców na Polskę, II wojna światowa, a u jej początków Sonderaction Krakau. Brutalny zamach okupantów niemieckich na wiodący Uniwersytet polski uderzył w jego profesorów i studentów, zarówno Wydziału Teologicznego, jak i innych wydziałów. Wspólnie razem przeżywali gehennę niemieckich obozów zagłady, których niejednokrotnie nie przeżyli. Mimo tego, mimo prześladowań okupanta, Wydział Teologiczny wraz z całym uniwersytetem nie zaprzestał działalności naukowej i dydaktycznej, lecz prowadził ją potajemnie w podziemiu z narażaniem życia profesorów i studentów ${ }^{13}$.

\footnotetext{
${ }^{11}$ Statut Uniwersytetu Papieskiego Jana Pawła II (dalej: Statut UPJPII), art. 1.

${ }^{12}$ Bulla Eximiae devotionis affectus, tekst łaciński i polski opublikowany w „Analecta Cracoviensia” 9 : 1977, s. 5-6.

${ }^{13}$ Por. Jan Paweł II, Motu proprio Beata Hedvigis, 8 XII 1981, „Notificationes” 120 : 1982, s. 69.
} 
Po zakończeniu II wojny światowej Uniwersytet Jagielloński wraz z Wydziałem Teologicznym bezzwłocznie przystąpił do odbudowy wyniszczonej okupacją nauki i kultury polskiej. Niedługo jednak Wydział Teologiczny mógł pracować dla dobra Ojczyzny i Kościoła. Tym razem komunistyczni naśladowcy totalitaryzmu hitlerowskiego usunęli Wydział Teologiczny z Uniwersytetu, pod pozorem przeniesienia go do Warszawy. Było do 11 sierpnia 1954 roku $^{14}$. Cios ten, mogłoby się wydawać śmiertelny, nie unicestwił Wydziału Teologicznego, gdyż zatroszczyła się o niego Stolica Apostolska. Swoim dekretem postanowiła, że Wydział Teologiczny istnieje i działa nadal w Krakowie, poza strukturami Uniwersytetu i pozostaje jedynie pod zarządem Stolicy Apostolskiej i kieruje się tylko prawodawstwem kościelnym ${ }^{15}$. W ten sposób Wydział Teologiczny stał się niezależny od komunistycznych władz państwowych w Polsce, zarządzany przez władzę kościelną i prowadzący działalność według przepisów kanonicznych.

W rezultacie przywołanych wydarzeń, usunięcia Wydziału z Uniwersytetu i wyłącznego przejęcia go przez władzę kościelną, rozpoczął się nowy rozdział $\mathrm{w}$ jego dziejach. Były to dzieje bardzo trudne, połączone $\mathrm{z}$ ciągłym prześladowaniem przez władze komunistyczne, ale równocześnie dzieje wspaniałe, połączone z jego rozwojem. Z punktu widzenia ludzi wierzących Opatrzność Boża w szczególniejszy sposób zaopiekowała się Wydziałem, co przejawiło się także tym, że posłani przez Nią ludzie zatroszczyli się o Wydział, bronili go i starali się o jego rozwój. Tu trzeba koniecznie wymienić kard. Karola Wojtyłę, a potem Jana Pawła II i wielu innych. Sprawa ta wymaga odrębnego omówienia, zresztą na ten temat ukazały się już pewne publikacje ${ }^{16}$.

Przedstawiając genezę statutu Uniwersytetu Papieskiego, zwrócimy uwagę jedynie na te wydarzenia znajdujące się w dokumentach, które przygotowały i miały wpływ na postanowienia aktualnego statutu. Dnia 11 czerwca 1974 roku Święta Kongregacja Wychowania Katolickiego wydała dekret przyznający Wydziałowi Teologicznemu tytuł „Papieski” ${ }^{17}$. Było to wyrazem jego dowartościowania i uznaniem dla jego osiągnięć i rozwoju. W tym samym dniu Kongregacja zatwierdziła statut Papieskiego Wydziału Teologicznego składający się z 47 artykułów $^{18}$.

Dalszy rozwój teologicznej uczelni Krakowa sprawił, że Papieski Wydział Teologiczny został przekształcony w Papieską Akademię Teologiczną w Krakowie. Papież Jan Paweł II postanowił: ,ustanawiamy na zawsze i erygujemy mocą tego

${ }^{14}$ Por. tamże.

${ }^{15}$ Dekret Świętej Kongregacji Seminariów i Studiów Uniwersyteckich, 16 XII 1959, N. 2295(59)4, opublikowany w Statut PAT, s. 117.

${ }^{16}$ Por. A. Kubiś, Papieski Wydział Teologiczny w Krakowie 1954-1981, [w:] Wyższe szkolnictwo kościelne w Polsce, red. J. Majka, Kraków 2002, s. 9-164; por. J. Dyduch, Troska kard. Karola Wojtyly o Wydział Teologiczny w Krakowie, „Analecta Cracoviensia” 26 : 1994, s. 295-313.

${ }^{17}$ AAS $67: 1975$, s. 149-150.

${ }^{18}$ Dekret Kongregacji Wychowania Katolickiego, N. 321(70)35, opublikowany w Statut PAT, s. 119. 
pisma i powagą naszą apostolską Papieską Akademię Teologiczną w Krakowie [...]”"19. Następnie został przygotowany nowy statut Papieskiej Akademii, uwzględniający jej aktualną sytuację oraz otwierający możliwość jej dalszego rozwoju. Statut ten został zatwierdzony przez Kongregację Wychowania Katolickiego 8 grudnia 1983 roku. Składał się on z norm ogólnych liczących 98 artykułów i norm szczegółowych, dotyczących poszczególnych wydziałów: Wydział Teologiczny - 50 artykułów, Wydział Filozoficzny - 13 artykułów i Wydział Historii Kościoła - 12 artykułów. Kongregacja zatwierdziła statut na okres pięciu lat, według formuły ad experimentum ${ }^{20}$. 16 października 1991 roku odnowiony statut PAT, składający się ze 191 artykułów, został zatwierdzony przez Kongregację według formuły donec aliter provideatur ${ }^{21}$, co oznacza, że statut został zatwierdzony na stałe, chyba że zaistniałaby potrzeba jego zmiany.

Taka potrzeba zaistniała wówczas, gdy starania o Uniwersytet Papieski w Krakowie dobiegały końca. Mianowicie delegacja PAT, w składzie rektor ks. Jan Dyduch i prorektorzy ks. Tadeusz Dzidek i ks. Kazimierz Panuś, 26 maja 2009 roku została przyjęta na specjalnej audiencji przez kard. Zenona Grocholewskiego, prefekta Kongregacji Edukacji Katolickiej. Wówczas to delegacja wręczyła Kardynałowi Prefektowi całokształt poszerzonej i uzupełnionej dokumentacji dotyczącej erygowania Uniwersytetu Papieskiego, zawierającej także projekt nowego statutu, uchwalonego przez senat PAT 23 lutego 2009 roku. Po ogólnym przejrzeniu Kardynał Prefekt przyjął dokumentację i obiecał, że Uniwersytet zostanie erygowany w ciągu miesiąca, natomiast prace nad statutem podejmie Kongregacja po wakacjach.

30 września 2009 roku kard. Z. Grocholewski skierował pismo do kard. S. Dziwisza, w którym napisał:

Po zbadaniu z należną uwagą wspomnianych statutów, niniejszym pozwalamy sobie przedstawić Waszej Eminencji niektóre uwagi (załącznik), aby wskazać uzupełnienia, które wydaje się nam trzeba wprowadzić, zgodnie zarówno z konstytucją apostolską Sapientia Christiana, jak i z praktyką akademicką 22 .

Stosownie do uwag Kongregacji został poprawiony i uzupełniony projekt statutu i przesłany do niej ponownie w dniu 26 grudnia 2009 roku. Trzeba dodać, że w piśmie przewodnim do Kongregacji wyjaśniono ze strony Uniwersytetu, dlaczego nie wprowadzono niektórych sugestii i propozycji przesłanych z Kongregacji ${ }^{23} .5$ lutego

\footnotetext{
${ }^{19}$ Motu proprio Beata Hedvigis, 8 XII 1981, „Notificationes” $120: 1982$, s. 68-70.

${ }^{20}$ Dekret Świętej Kongregacji Wychowania Katolickiego, 8 XII 1983, opublikowany w Statut PAT, s. 120.

${ }^{21}$ Dekret Świętej Kongregacji Wychowania Katolickiego, 16 IX 1991, opublikowany w Statut PAT, s. 121.

${ }^{22}$ N. 641/81, Archiwum UPJPII.

${ }^{23}$ Pismo kard. S. Dziwisza, 26 XII 2009, Archiwum UPJPII.
} 
2010 roku Kongregacja Edukacji Katolickiej zatwierdziła statut Uniwersytetu na pięć lat ${ }^{24}$.

\section{Idee wiodące}

Statut UPJPII w Krakowie odzwierciedla jego kościelny charakter. Powiedzieliśmy wyżej, że zgodnie z konstytucją apostolską Sapientia Christiana priorytetowym celem uniwersytetu kościelnego jest ewangelizacja. Statut kilkakrotnie podkreśla, że Uniwersytet Papieski w Krakowie prowadzi działalność ewangelizacyjną: „Celem Uniwersytetu jest: zgłębianie depozytu wiary, rozwijanie badań z zakresu filozofii i innych dyscyplin naukowych"25. Uniwersytet Papieski jest prawdziwym uniwersytetem, a taka uczelnia gwarantuje wolność badań i nauczania, jednak tu wolność nie może przekształcić się w samowolę. Dlatego dydaktyka Uniwersytetu ma swoje ramy, a stanowi je Magisterium Kościoła. Statut postanawia: „Uniwersytet troszczy się zarówno o właściwą wolność w badaniach naukowych i nauczaniu, jak i o wierność Magisterium Kościoła"26.

W działalności Uniwersytetu obowiązują metody naukowe, ale ważne jest również przekazywanie wiary żywej: „W nauczaniu uwzględnia się metody naukowo-dydaktyczne właściwe każdej z dyscyplin. Należy ukazywać studentom związek życia z wiarą, uczyć ich szacunku dla prawdy, poszanowania ludzkiej godności i kultury oraz pobudzać do stałego pogłębiania wiedzy"27. Badania naukowe i dydaktyka jako przedmiot mają Objawienie Boże i w jego świetle rozwiązywanie współczesnych trudności i problemów: „Badania naukowe i nauczanie winny być ukierunkowane na pogłębianie znajomości prawdy zawartej w Objawieniu chrześcijańskim i na rozwiązywaniu w jego świetle problemów, przed którymi stoi Kościół”28. Szczególne zadania ewangelizacyjne stoją przed Wydziałem Teologicznym Uniwersytetu: „Celem Wydziału Teologicznego jest wszechstronne i systematyczne badanie Bożego Objawienia w różnych epokach i przejawach życia Kościoła oraz człowieka"29.

Kolejną ideą wiodącą statutu Uniwersytetu jest jego autonomia wobec władz świeckich. Ta idea ma głębokie korzenie w historii polskich uczelni kościelnych i katolickich ostatnich dziesiątków lat. Ukształtowała się ona zwłaszcza w walce o tę autonomię podczas panowania dyktatury komunistycznej, która usiłowała zawładnąc i całkowicie podporządkować sobie naukę katolicką. Temu zdecydowanie przeciwstawili się ludzie Kościoła, wśród których wiodącą rolę odegrał kard. Karol Wojtyła. Jego ideą przewodnią było hasło „Kościół sam ma stanowić o swojej

\footnotetext{
${ }^{24}$ Dekret Kongregacji Edukacji Katolickiej, 5 II 2010, N. 641/81, Archiwum UPJPII.

${ }^{25}$ Statut UPJPII, art. 5.

${ }^{26}$ Tamże, art. 105.

${ }^{27}$ Tamże, art. 106.

${ }^{28}$ Tamże, art. 107.

${ }^{29}$ Tamże, art. 135.
} 
nauce". Aby zapewnić należną wolność nauce katolickiej i autonomię uczelniom kościelnym i katolickim, podjął starania o powołanie specjalnego organu, który by się o nią zatroszczył. Takim organem stała się Rada Naukowa Episkopatu Polski. Utworzyła ją Konferencja Episkopatu Polski w 1973 roku, jej przewodniczącym został kard. Karol Wojtyła ${ }^{30}$. Uwieńczeniem idei dotyczącej samostanowienia Kościoła w Polsce o nauce katolickiej jest erygowanie Uniwersytetu Papieskiego w Krakowie. Tak tę sprawę postrzega kard. Marian Jaworski:

Niewątpliwe jest jednak, że ukoronowaniem tej idei kard. Karola Wojtyły jest powołanie przez Ojca Świętego Benedykta XVI Uniwersytetu Papieskiego Jana Pawła II w Krakowie. Jest to nie tylko ranga, która została przyznana tej uczelni, ale nade wszystko realizacja w pełni idei kard. Karola Wojtyły: „Kościół sam stanowi o swej nauce” ${ }^{31}$.

Opinia ta jest ważna i miarodajna także dlatego, że jej autor ma znaczący wkład w obronę autonomii polskich uczelni kościelnych i był najbliższym współpracownikiem Karola Wojtyły w walce o ich autonomię. Ostatecznie autonomię wyższych uczelni kościelnych i katolickich w Polsce gwarantuje Konkordat: „Rzeczpospolita Polska gwarantuje Kościołowi katolickiemu prawo do swobodnego zakładania i prowadzenia szkół wyższych, w tym uniwersytetów, odrębnych wydziałów i wyższych seminariów duchownych oraz instytucji naukowo-badawczych"32.

Statut Uniwersytetu swoimi postanowieniami wyraża jego autonomię w wieloraki sposób. Najpierw podkreślając, że Uniwersytet w swojej działalności kieruje się przede wszystkim kanonicznym prawodawstwem, zawartym zwłaszcza w Kodeksie prawa kanonicznego i konstytucji apostolskiej Sapientia Christiana ${ }^{33}$. Nadrzędną władzę nad Uniwersytetem sprawuje papież za pośrednictwem Kongregacji Edukacji Katolickiej. Jest to gwarancja autonomii i niezależności od władz świeckich, która jest potrzebna do działalności Uniwersytetu Papieskiego. Statut wielokrotnie zaznacza relacje Uniwersytetu Papieskiego ze Stolicą Apostolską, konkretnie z Kongregacją Edukacji Katolickiej. Istotne działanie Uniwersytetu, jakim jest nadawanie tytułów naukowych, stopni naukowych i tytułów zawodowych, angażuje autorytet Stolicy Apostolskiej: „Uniwersytet zajmuje się badaniem i przekazywaniem wiedzy teologicznej i innych nauk humanistycznych, nadaje tytuły zawodowe, stopnie naukowe i tytuł naukowy powagą Stolicy Apostolskiej”34. Bliska łączność i bezpośrednia współpraca Uniwersytetu Papieskiego i Stolicy Apostolskiej jest prowadzona przez wielkiego kanclerza Uniwersytetu, którym jest arcybiskup krakowski oraz przez wielkiego wicekanclerza, którym jest biskup tarnowski. Statut wylicza ich

${ }^{30}$ Por. J. Dyduch, Kardynat Karol Wojtyła w stużbie Konferencji Episkopatu Polski, Kraków 2007, s. 112-125.

${ }^{31}$ Wykład podczas pierwszej inauguracji roku akademickiego 2009/2010 w Uniwersytecie Papieskim Jana Pawła II w Krakowie, opublikowany w materiałach z inauguracji, Kraków 2009, s. 15.

${ }^{32}$ Konkordat między Stolicą Apostolską i Rzecząpospolitą Polską, 28 VII 1993, art. 15.

${ }^{33}$ Por. Statut UPJPII, art. 3.

${ }^{34}$ Tamże, art. 2. 
kompetencje, wśród których podstawowe znaczenie ma reprezentowanie Stolicy Apostolskiej wobec Uniwersytetu i Uniwersytetu wobec Stolicy Apostolskiej ${ }^{35}$. Stolica Apostolska zatwierdza wybory na ważniejsze urzędy sprawowane na Uniwersytecie, w tym wybór rektora, wybór dziekanów poszczególnych wydziałów i dyrektora Instytutu Prawa Kanonicznego ${ }^{36}$. Stolica Apostolska wydaje również nihil obstat na ważne funkcje dydaktyczne, którymi są: tytuł profesora oraz stanowisko profesora nadzwyczajnego i zwyczajnego, jak również na doktorat honorowy ${ }^{37}$. Zatwierdza ona także statut Uniwersytetu ${ }^{38}$. Aktualny statut, jak już wspominaliśmy, został zatwierdzony dekretem Kongregacji Edukacji Katolickiej z 5 lutego 2010 roku ${ }^{39}$.

Wydaje się, że Konkordat z 1993 roku oraz statut Uniwersytetu Papieskiego wystarczająco zabezpiecza jego autonomię i niezależność wobec władz świeckich. Trzeba jednak dodać, że Uniwersytet Papieski funkcjonuje w ramach państwa polskiego, jest uznawany przez władze państwowe, dlatego w pewnym ściśle określonym zakresie jest zobowiązany stosować się do polskiego prawodawstwa państwowego. Potwierdza to statut:

Status prawny i działalność Uniwersytetu Papieskiego Jana Pawła II w Krakowie opiera się również na postanowieniach Konkordatu między Stolicą Apostolską a Rzecząpospolitą Polską z 28 lipca 1993 r. oraz Umowy zawartej 1 lipca 1999 r. pomiędzy Rządem Rzeczypospolitej Polskiej a Konferencją Episkopatu Polski w sprawie uregulowania statusu wyższych uczelni papieskich w Polsce, uwzględniając także obowiązujące prawodawstwo państwowe o szkolnictwie wyższym ${ }^{40}$.

Zakres stosowania przez Uniwersytet Papieski prawodawstwa państwowego określa przede wszystkim przywołana Umowa z 1 lipca 1999 roku. Jest ona wcześniejsza od zatwierdzenia statutu, stąd uwzględnia on jej ustalenia.

W związku z tym statut prezentuje kolejną ideę wiodącą, jaką jest uwzględnienie polskiego prawodawstwa państwowego dotyczącego szkolnictwa wyższego. Chodzi w pierwszej kolejności o kompatybilność i równoważność tytułów i stopni naukowych przewidzianych prawem kanonicznym i prawem państwowym. Statut postanawia:

Uniwersytet Papieski Jana Pawła II w Krakowie nadaje następujące stopnie i tytuły: 1) tytuł licencjata zawodowego - równoważny stopniowi bakalaureatu na Wydziale Filozoficznym, Wydziale Historii i Dziedzictwa Kulturowego, Wydziale Nauk Społecznych. Na Wydziale Teologicznym tytułu licencjata zawodowego nie nadaje się; 2) Tytuł zawodowy magistra - równoważny stopniowi bakalaureatu na Wydziale Teologicznym, zaś na Wydziale Filozoficznym, Wydziale Historii i Dziedzictwa Kulturowego, Wydziale Nauk Społecznych równoważny stopniowi licencjata naukowego (kościelnego); 3) Stopień licencjata naukowego (kościelnego) nadawany na Wydziałach Teologicznych i w Instytucie Prawa Kanonicznego; 4) stopień naukowy doktora; 5) stopień naukowy doktora habilitowanego; 6) tytuł naukowy profesora ${ }^{41}$.

\footnotetext{
${ }^{35}$ Por. tamże, art. 12 i 13.

${ }^{36}$ Por. tamże, art. 28, p. 2, art. 43, art. 176.

${ }^{37}$ Por. tamże, art. 12 , p. 8 i 13 , art. 58, art. 59.

${ }^{38}$ Por. tamże, art. 12, p. 3.

${ }^{39}$ Dekret, N. 641/81, 5 II 2010, [w:] Statut UPJPII, s. 1.

${ }^{40}$ Statut UPJPII, art. 3.

${ }^{41}$ Tamże, art. 115.
} 
Wszystkie wymienione stopnie i tytuły są nadawane w Uniwersytecie Papieskim zgodnie z przepisami państwowymi i kościelnymi ${ }^{42}$. Dzięki temu wszystkie one są uznawane w państwie polskim ${ }^{43}$. Oddzielnie jest potraktowany licencjat naukowy (kościelny), który nie ma odpowiednika w prawodawstwie polskim. Statut Uniwersytetu jest dostosowany do wymogów „Procesu bolońskiego”, wprowadzonego w Unii Europejskiej i przyjętego przez Stolicę Apostolską. Wyrazem tego jest, między innymi, wprowadzenie dwustopniowych studiów podstawowych na Wydziale Filozoficznym, Wydziale Nauk Społecznych oraz Wydziale Historii i Dziedzictwa Kulturowego. Po ukończeniu pierwszego stopnia tychże studiów nadaje się tytuł zawodowy licencjata, a po ukończeniu drugiego stopnia tytuł zawodowy magistra ${ }^{44}$.

\section{Struktura statutu}

Statut Uniwersytetu zawiera wstęp historyczny połączony z wykazem dokumentów kształtujących w przeszłości i aktualnie jego działalność. Znajduje się tam uzasadnienie jego nazwy: „Uniwersytet Papieski Jana Pawła II w Krakowie zachowuje we wdzięcznej pamięci wszystko to, co dla jego przetrwania i rozwoju uczynił Karol Wojtyła, najpierw jako kardynał i arcybiskup metropolita krakowski, a następnie jako papież Jan Paweł II" ${ }^{45}$. Statut wymienia cele uczelni, opisuje jej strukturę, normuje funkcjonowanie wspólnoty akademickiej, prowadzenie badań naukowych, dydaktykę, nadawanie stopni i tytułów, współpracę z innymi uczelniami, reguluje sprawy wydawnicze, administracyjne i ekonomiczne, jak również działalność bibliotek. Zajmuje się poszczególnymi wydziałami Uniwersytetu i Instytutem Prawa Kanonicznego. Statut normuje zatem całokształt tych spraw, których uregulowania domaga się prawodawstwo kanoniczne i prawodawstwo państwowe. Stąd co do istoty statut Uniwersytetu Papieskiego nie odbiega od statutów uczelni kościelnych i katolickich w Polsce, ani od statutów polskich uczelni publicznych.

Nie jest zadaniem niniejszego artykułu omawiać poszczególnych przywołanych wyżej zagadnień, czy tym bardziej poszczególnych norm. Zagadnienie to wymaga odrębnego opracowania. Zajmiemy się jedynie niektórymi sprawami, charakterystycznymi dla Uniwersytetu Papieskiego w Krakowie. Wspólnota akademicka składa się z władz kolegialnych i indywidualnych, z pracowników naukowych i dydaktycznych, administracyjnych i studentów. Władze wspólnoty uniwersyteckiej są następujące: „W stosunku do całego Uniwersytetu władzę - zgodnie ze swoimi kompetencjami - posiadają wielki kanclerz, rektor, senat uczelni, a w stosunku do poszczególnych wydziałów: dziekan i rada wydziału. Ponadto w stosunku do Wydziału Teologicznego

\footnotetext{
${ }^{42}$ Por. tamże, art. 116-121, art. 123.

${ }^{43}$ Por. Umowa z 1 VII 1999, § 6. $1, \S 8, \S 9.1$.

${ }^{44}$ Por. Statut UPJPII, art. 116 i 117.

${ }^{45}$ Tamże, art. 4.
} 
Sekcja w Tarnowie, władzę posiada wielki wicekanclerz" "46. Jak już wspominaliśmy, funkcja wielkiego kanclerza i wielkiego wicekanclerza nie występuje w uczelniach państwowych. Statut daje im realną, nie tylko honorową władzę w Uniwersytecie. Jest ona określona najpierw ogólnie: „Wielki kanclerz, którym jest arcybiskup metropolita krakowski: 1. troszczy się o dobro i rozwój Uniwersytetu, popiera badania naukowe i pracę dydaktyczną Uczelni, czuwa nad czystością nauki katolickiej, dobrymi obyczajami i dyscypliną całej wspólnoty uniwersyteckiej, dba o jedność Uczelni i jej łączność z Kościołem powszechnym i lokalnym, zabezpiecza środki materialne, udzielając odpowiednich pełnomocnictw w tym zakresie" ${ }^{97}$. Z kolei wielokrotnie statut określa szczegółowe kompetencje wielkiego kanclerza ${ }^{48}$.

Statut wiele uwagi poświęca pracownikom Uniwersytetu. Najogólniej stwierdza: „Pracownikami Uniwersytetu mogą być osoby o odpowiednich kwalifikacjach, które wiernie przyjmują doktrynę katolicką, kierują się w życiu zasadami etyki katolickiej, dobrze wypełniają swoje obowiązki i troszczą się o dobro Uniwersytetu" ${ }^{\text {"49 }}$. Ta ogólna zasada dopuszcza wyjątki. Mogą być zatrudnione osoby, nawet jako nauczyciele akademiccy, wyznające inną religię lub nie wyznające żadnej religii, o ile zaakceptują katolicki charakter uczelni ${ }^{50}$. Trzeba podkreślić, że chodzi tu o sytuację wyjątkową i o zatrudnienie w nauczaniu przedmiotów niezwiązanych z doktryną katolicką, np. technika prowadzenia wywiadów na kierunku dziennikarstwo. Szczególne miejsce w statucie Uniwersytetu zajmują jego studenci: „Studentami Uniwersytetu Papieskiego Jana Pawła II w Krakowie mogą być osoby, które uzyskały świadectwo dojrzałości, zobowiązują się uznawać i szanować katolicki charakter Uniwersytetu oraz kierują się zasadami moralności chrześcijańskiej”" ${ }^{\text {. }}$. Na podjęcie studiów przez duchownych wymagane jest dodatkowe zezwolenie ich ordynariusza, zaś przez osoby zakonne - zezwolenie ich wyższego przełożonego ${ }^{52}$. Studentom Uniwersytetu przysługują wszystkie prawa studentów określone w prawie państwowym, zgodnie z postanowieniami umów między Rządem RP i Konferencją Episkopatu Polski ${ }^{53}$.

Specyfiką Uniwersytetu Papieskiego, przejętą od Papieskiego Wydziału Teologicznego i PAT, jest zawieranie umów o współpracy naukowej z instytutami teologicznymi i wyższymi seminariami duchownymi. Ich inicjatorem i inspiratorem był kard. Karol Wojtyła. Umożliwiają one studentom uzyskiwanie stopni magisterskich, a wykładowcom powiększania kwalifikacji naukowych ${ }^{54}$. Dzięki

${ }^{46}$ Tamże, art. 11.

${ }^{47}$ Tamże, art. 12, p. 1.

${ }^{48}$ Por. tamże, art. 12-13, 28, 31, 57, 58, 64, 65, 122, 143.

${ }^{49}$ Statut UPJPII, art. 52.

${ }^{50}$ Por. tamże, art. 53.

${ }^{51}$ Tamże, art. 73.

${ }^{52}$ Por. tamże, art. 75.

${ }^{53}$ Por. tamże, art. 80.

${ }^{54}$ Por. J. Dyduch, Papież Jan Pawet II, protektor Papieskiej Akademii Teologicznej, [w:] Sympozjum naukowe z okazji 15-lecia pontyfikatu Jana Pawła II, red. J. Szczurek, Kraków 1994, s. 116. 
tym umowom magisterium na naszej Uczelni uzyskało ponad 13 tys. absolwentów wyższych seminariów duchownych i instytutów teologicznych związanych z nią umową o współpracy naukowej. Sprawa jest nadal aktualna. Podczas starań o przekształcenie PAT w Uniwersytet liczba takich umów zatwierdzonych przez Stolicę Apostolską wynosiła dwadzieścia ${ }^{55}$. Dlatego sprawa ta musiała znaleźć odzwierciedlenie w nowym statucie Uniwersytetu. Norma podana w jego projekcie została zakwestionowana przez Kongregację Edukacji Katolickiej, która zaproponowała, aby określenie „umowa o współpracy naukowej” zastąpić terminem „,afiliacja do Wydziału Teologicznego"56. W odpowiedzi, w imieniu Uniwersytetu Papieskiego jego Wielki Kanclerz wyjaśnił, że w statucie nie można zrezygnować z określenia „umowa o współpracy naukowej” ze względu na to, że występuje ono w Umowie między Konferencją Episkopatu Polski i Rządem RP, dzięki której magisteria nadawane przez Uniwersytet Papieski są uznawane przez państwo polskie ${ }^{57}$.

W przesłanym, poprawionym projekcie statutu Uniwersytet Papieski w Krakowie zaproponował następującą normę: „Zgodnie z przepisami prawa, z Wydziałem Teologicznym współpracują, na mocy podpisanych przez Uniwersytet i zatwierdzonych przez Stolicę Apostolską umów o współpracy naukowej (odpowiada afiliacji według konstytucji Sapientia Christiana), inne instytucje teologiczne, w szczególności seminaria duchowne, których studenci, po spełnieniu właściwych wymagań, uzyskują tytuł zawodowy magistra teologii - równoważny stopniowi bakalaureatu - nadawany przez Wydział Teologiczny"58. Przywołany tekst został zaakceptowany przez Kongregację i wszedł do statutu Uniwersytetu ${ }^{59}$.

Krakowska uczelnia teologiczna, sięgająca swymi początkami 1397 roku, kształtowała swój profil, strukturę i zadania poprzez wieki. Służyły temu dokumenty kościelne i państwowe, w oparciu o które układane były jej statuty. Utworzenie Uniwersytetu Papieskiego Jana Pawła II w Krakowie wymagało nowego statutu. Jego wiodące idee to: ewangelizacyjny cel Uniwersytetu, jego autonomia i niezależność od władz świeckich oraz sprecyzowanie funkcjonowania w rzeczywistości polskiej, czyli kompatybilność norm kanonicznych i norm państwowych dotyczących szkolnictwa wyższego. Statut normuje całą działalność wspólnoty akademickiej, jej władz, pracowników i studentów, jej współpracę z instytucjami naukowymi oraz działalność poszczególnych wydziałów Uniwersytetu. Statut został zatwierdzony przez Kongregację Edukacji Katolickiej 5 lutego 2010 roku.

\footnotetext{
${ }^{55}$ Pismo kard. S. Dziwisza, 15 X 2005, Archiwum UPJPII.

${ }^{56}$ Pismo kard. Z. Grocholewskiego, 30 IX 2009, N. 641/81, Archiwum UPJPII.

${ }^{57}$ Pismo kard. S. Dziwisza, 26 XII 2009, Archiwum UPJPII.

${ }^{58}$ Projekt Statutu UPJPII z 26 XII 2009, art. 138, Archiwum UPJPII.

${ }^{59}$ Statut UPJPII z 5 II 2010, art. 137.
} 


\section{Summary}

\section{Characteristics of the statute of the Pontifical University of John Paul II In Cracow}

Foundation of the Pontifical University of John Paul II on 19 June 2009 required a new statute. It was adopted by the university senate on 23 February 2009 and handed over to Cardinal Zenon Grocholewski, the prefect of the Congregation for Catholic Education, on 26 May 2009. After entering the observations of the congregation by the Pontifical University of John Paul II in Cracow, it was approved by the congregation on 2 May 2010. The statute regulates the activity of the entire academic community and its individual faculties. It emphasizes evangelisation tasks of the university, its independence and autonomy to the civil authorities and compatibility of the canonical norms and the regulations of state for the universities.

\section{Keywords}

Cardinal Zenon Grocholewski, canon law, Catholic Church, Congregation for Catholic Education, John Paul II, the Pontifical University of John Paul II in Cracow, statute 